“Ténotomie du Muscle Tenseur du Tympan," Progrès Médical, 1878 in 8,1878 (Delahaye).

"De la Rhinorrhagie chez les herpétiques et les Buveurs," Abeille Mídi. cale, 1881.

"Considérations Anatomiques et Physiologiques sur la Trompe d'Eustache avec le Dr. Baratoux," Progrès Médical, 1881 in 8 (Delahaye).

"Traité Thèorique et Pratique des Maladies de l'Oreille et du Nez, avec le Dr. Baratoux," I fascicule, 1884, Paris (Delahaye); 2e fascicule, 1888.

"Réflexions sur l'Obstruction de la Trompe d'Eustache chez un Diabétique ;" "Des Pressions Centripèdes et Centrifuges sur la Membrane du Tympan au point de vue du Diagnostic et du Traitément," Société Française d'Otologie et de Laryngologie, Avril, 1887; Revue Mensuelle de Laryngologie, d'Otologie, et de Rhinologie, No. 7, 1887, Juin 8, 1887. Paris (Doin).

“ De l'Obstruction des Fosses Nasales Consécutive à l'Hypertrophie Quadrangulaire de la Cloison," Sociéte Française d'Otologie, de Laryngologie, Avril, 1888; Revue Mensuelle des Laryngologie, d'Otologie, et de Rhinologie, Nos. 5 et 6, 1888, Juin 8, 1888 (Doin).

1890- " De la Mobilisation de l'Étrier" (lu en Grande Partie au Congrès d'Otologie et de Laryngologie de Paris en Septembre, 1889); Revue de Laryngologie, d'Otologie, et de Rhinologie, Nos. 2, 3, 4, et 5 (Doin).

1891- "De l'Extraction du Tympan et d'une Partie de la Chaine des Osselets dans l'Otite Moyenne Sèche," extrait de la Revue de Laryn. gologie, d'Otologie, et de Rhinologie, 1891 (Doin).

1894-_."Epistaxis Grave," "De la Mobilisation de l'Etrier" (communications faites à la Société Française de Laryngologie, d'Otologie, et de Rhinologie, Congrès de 1894); tirage à part de la Revue de Laryngologie, d'Otologie, et de Rhinologie, No. 11, 1894 (Doin).

1897 -." Corps Etranger dans le Sinus Maxillaire" (extrait de la Revue Générale de Clinique et de Thérapeutique), Journal des Praticiens.

"De la Guérison des Perforations Tympaniques par l'Acide Trichloracétique" (extrait des “Bulletin et Mémoires de la Sté. Français d’Otologie, de Laryngologie, et de Rhinologie "), Congrès de 1898.

1898- "Un Cas de Rhinolithe" ("Bulletins et Mémoires de la Sté. Française d'Otologie, de Laryngologie, et de Rhinologie"), Congrìs de 1898.

\title{
EDITORIAL
}

\section{THE OTOLOGICAL SOCIETY OF THE UNITED KINGDOM AT GLASGOW.}

Tне extra-metropolitan meetings of this Society have in every instance been highly successful, and the latest one, which was held at Glasgow on May 21, was no exception to the rule. The Society has eminently justified its title as "of the United Kingdom." A number of prominent members journeyed north from London and other parts of England and Ireland, and the Scottish members appeared in full force. The programme was well arranged and most interesting, but if it erred it was in the superabundance of 
JOURNAL OF LARYNGOLOGY, RHINOLOGY, ANI OTOLOGY.

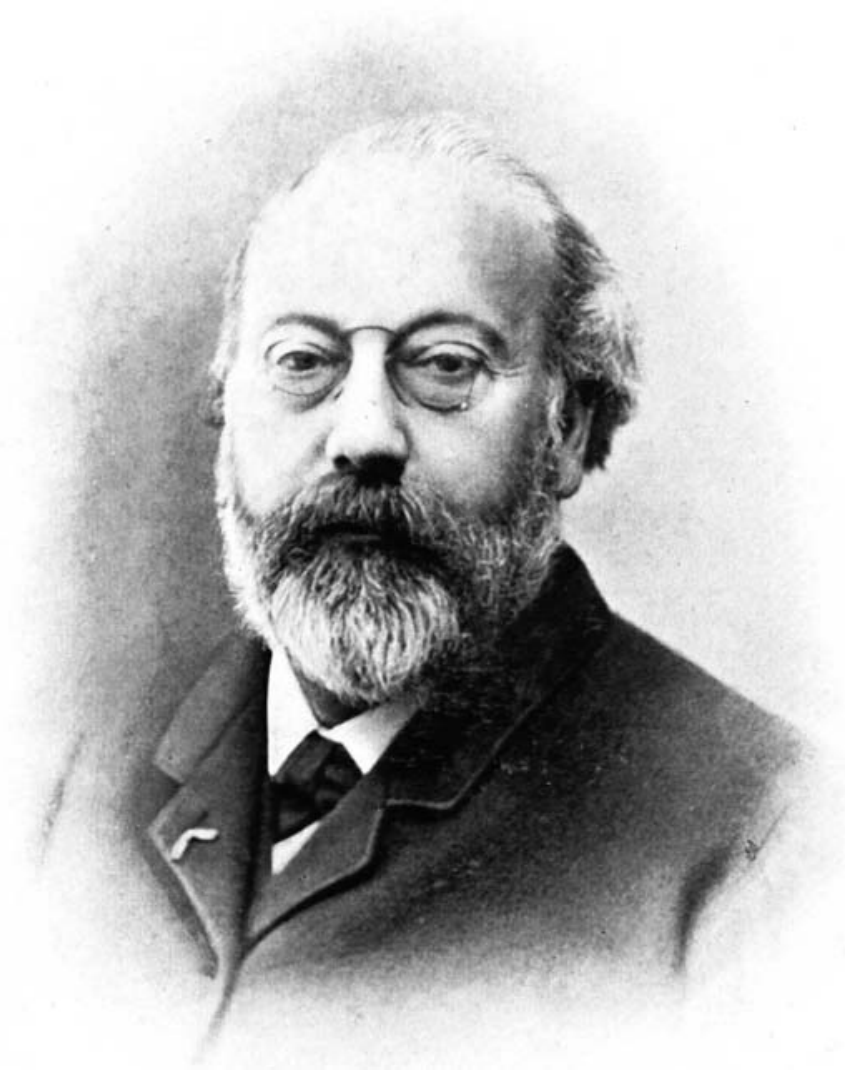

'ThE LATE DR. ('AMILLE MIOT, GF PAKIS. 
material, and many items of interest had, unfortunately, to be taken as read.

The Society is indebted to Professor Cleland for a long and dutailed account of some points in the development of the mastoid an tympanic plate, which ought to prove very interesting reading. Th. Mr.Bride's note on a case in which absence of the antrum was riagnosed during operation gave rise to an animated discussion. Mr. Cheatle commented on the use of the term "absence," and asked for the substitution of the term "obliteration." This involves a theory which, however, we consider Dr. McBride's description fully supports, namely, that the "absence" was the result of "obliteratim " produced by inflammatory thickening.

Mr. R. H. Parry's brilliant operation of division of the eighth nepre was considered with well-deserved attention by all, while it wis received with what we are inclined to think rather more strere criticism at the hands of some of the members than the circumstances demanded. We feel bound to support the opinion that it would have been better in the first instance to perform the ratical mastoid operation. A part from this, however, Mr. Parry's detailed description of the method by which he exposed the structures in the internal anditory meatus is worthy of the greatest attention. The patient recovered, and his sufferings were consilerably mitigated. An unfortunate incident was the division of the facial nerve brought about by the removal of a detached purtion of bone which turned out to be in the form of a ring smounding the facial nerve. Apart from this, Mr. Parry states that the exposure of the parts was so complete that he would have had no difficulty in dividing the auditory without the facial nerve. The subsequent facio-accessory anastomosis was so far sncessful that the facial muscles acted very vigorously, but only when the shoulder was raised. The accessory was said to have hen completely divided, which is probably the most effective Imceeding, as shown by Mr. Ballance's series of cases. In one of these the face could be moved independently of the shoulder. Mr. Ballance stated that theoretically the facial should be anastumosed with the hypoglossal rather than the accessory. We may recall to our readers the abstract of a case published by Körte (Jocrsal as Laryagogry, 1903, p. 446), in which is described the unhappy plight of a patient in whom the facio-hypoglossal anastomosis had been effected. For several months the paralysis of the tongue along with that of the buccinator made eating most difficult. Mr. Ballance's case with complete division of the fibres of the accessory probably shows the best obtainable result. 
The clou of the meeting was perhaps Mr. Lake's case of vertigo, in which he burred away all the semicircular canals of one side, and which drew from Dr. Milligan the account of two cases in which he had performed the same operation.

Dr. J. H. Nicoll broke new ground in relation to the jugular vein. He recommended that in case of laceration of the upper part of the jugular vein his example should be followed of rapidly exposing the sigmoid sinus and obliterating it by pressure. The accident was apt to occur during the removal of tuberculous cervical glands in children, in whom the exposure of the sigmoid sinus could be very rapidly effected. In an operation for malignant disease of the tonsil he had ligatured the external carotid and plugged the lateral sinus. Apart from the indications generally received in cases of lateral sinus phlebitis, he had in some cases of tuberculosis of the petrous bone performed preliminary ligature of the internal jugular, especially in the presence of tuberculous glands. In this way he forestalled the possibility of tuberculous material being drawn into the large veins.

It will be seen that some eminently "progressive" steps in aural surgery characterised this meeting, and one may almost be forgiven for comparing the aural surgeon to the "sappeur" to whom, the French say, " rien n'est sacré."

Thirteen out of the eighteen items on the programme had to be taken as read, but their interest will be evident from the report of the meeting. Several of them referred to patients present for examination before the proceedings commenced. Dr. Brown-Kelly showed one with insufficiency of the soft palate and notching of the hard palate. This last condition has apparently received little or no attention, and its clinical importance is apparently not very decided. As in another of his cases there was notching of the palate without insufficiency, and, in a third, insufficiency without notching. Dr. Brown-Kelly's observations will draw attention to the subject. One of the first cases of temporo-sphenoidal abscess successfully operated on by Sir Wm. Macewen was brought forward by the President. Among other cases was one shown by the President and Dr. Nicoll, in which a pulsating tinnitus heard through the auscultation tube was unrelieved by ligature of vessels. These were apparently the external carotid and the posterior auricular. Dr. Dundas Grant found them checked by pressure in the sub-occipital triangles, the spaces in which he had long ago shown that the vertebral arteries could be compressed. The pulsation took place, therefore, in the internal auditory artery, and was quite independent of the carotid circulation. 
Among the most interesting exhibits were a number of preparations by Dr. Albert Gray and Dr. Kerr Love.

Great regret was felt that the serious illness of Professor NcKendrick prevented him from giving the demonstration of experiments illustrating recent researches on the physical nature of rowel tones and their bearing on the movements of the tympanic nembrane. Dr. Colquhoun succeeded in interesting and instructing the Society by his admirable exposition and experimentation, but no one could reproduce the Professor's enthusiastic joy in the demonstration of material which his old students knew him to have so much at heart, and to which Dr. Colquhoun most feelingly referred. The demonstration refreshed the memory of the hearers with regard to much they had formerly learned, and brought them well up to the present state of knowledge of the subject.

The hospitality exercised by the President was greatly enjoyed, and gare point to Professor Urban Pritchard's post-prandial suggestion that the laws of the Society should be altered in order to admit of Dr. Barr being made Perpetual President.

\section{THE FIFTEENTH INTERNATIONAL CONGRESS OF MEDICINE, LISBON, APRIL, 1906.}

WE have received the first number of the Journal of the Fifteenth International Congress of Medicine, to be held in Lisbon from April 19 to 26, 1906. This number contains the regulations of the Congress, the organisation of the sections and of the different national committees. Under the second article of the regulations, besides doctors, only scientists introduced by the national or Portuguese committees can be admitted to the Congress.

The subscription is 25 francs or 20 marks or one pound sterling. The work of the Congress is distributed in 17 sections as follows:

1-Anatomy (Descriptive and Comparative Anatomy, Anthropology, Embryology, Histology).

2-Physiology.

3-General Pathology, Bacteriology, and Pathological Anatomy.

4-Therapeutics and Pharmacology.

5-Medicine.

6 -Pediatrics.

7-Neurology, Psychology, and Criminal Anthropology

8-Dermatology and Syphilography.

9-Surgery.

10-Medicine and Surgery of the Urinary Organs.

11-Ophthalmology. 